Article

\title{
Prioritizing Black Self-Determination: The Last Strident Voice of Twentieth-Century Black Nationalism
}

\author{
Bayyinah S. Jeffries \\ Department of African American Studies, Ohio University, Athens, OH 45701, USA; jeffrieb@ohio.edu
}

Received: 31 August 2020; Accepted: 18 November 2020; Published: 20 November 2020

\begin{abstract}
Black self-determination, like the movement for civil rights, has long been a struggle on both the national and international stage. From the Black consciousness campaign of South Africa to the Black Power crusades of the United States and Caribbean, and the recent global affirmations of Black Lives Matter, Black nationalist ideology and desires for equity and independence seem ever more significant. While marginal characteristics of Black nationalism clearly persist in the calls for justice and equality, only one voice of twentieth-century Black nationalism remains committed to the full dimensions of the Black nationalist agenda. This essay documents the one leader and movement that has remained committed to a Black nationalist platform as a response to persistent white supremacy. The author reflects on the valuable contributions of twentieth-century Black nationalism and what form, if any, Black nationalism will take when this last Black nationalist movement leader is gone.
\end{abstract}

Keywords: Black nationalism; Black self-determination; Black Muslims; Nation of Islam; reconstituted Nation of Islam; Louis Farrakhan

\section{Twentieth-Century Expressions of Black Nationalism}

In May 2019, one of the most powerful social media platforms, Facebook, banned Minister Louis Farrakhan. Twitter briefly suspended his account but reinstated it the same day. While Farrakhan and the NOI have been labeled anti-Semitic, they maintain a great deal of support from many in the Black community. The Nation of Islam continues to carry the banner of a doctrine that centers Black people, and encourages the work and perspective of Black self-determination, the centerpiece of Black nationalism. Self-determination is about self-definition. It also encourages the construction and control of Black institutions, prioritizes Black people, creates and legitimizes knowledge, and sets an agenda by and for Black people.

In 1964, Malcolm X defined Black nationalism as a moral, political and economic viewpoint. More importantly, he described it as a philosophy of self-determination, where Black people controlled every aspect of their own community, institutions and political economy. Historian William L. Van Deburg in his important work on modern Black nationalism outlines several nationalist perspectives including cultural, religious, political, revolutionary, educational and economic. In the case of Black nationalism, he described it as an ideology desirous of maintaining Black "sociocultural" and economic autonomy. Deburg's explanation of nationalism has been the most common approach. For the purpose of this work, Black nationalism is defined in order to capture the various dimensions expressed in the most popular groups of the time. ${ }^{1}$

1 Thank you to Michigan State University Archives, one of only a few libraries to own most copies of the Final Call newspaper (Malcolm 1964, pp. 589-603; Van Deburg 1997). 
Twentieth-century Black nationalism served as a movement, perspective, philosophy and work, which promoted Black consciousness, self-definition, Black success, beauty, business, health, religiosity, political agency, and overall Black self-determination and independence. Black nationalists set their own criteria for liberation, free from whites who sought to control them. Today, groups such as the People's New Black Panther Party, the Huey P. Newton Gun Club, The Black Riders Liberation Party, Washita Nation, the New Black Liberation Militia, and parties associated with Black Lives Matter, tap into the audacity and rhetoric of twentieth-century Black nationalism that made Black men such as Muhammad Ali, Malcolm X, and others so popular. The efforts and ideology of these contemporary groups and individuals, like the few mentioned above, demonstrate the influence of past Black nationalists who sought to address the "unresolved backlog of race-based social problems" in the United States in the most frank and unapologetic way. Still, these groups, and those who espouse Black nationalist sentiments today, have yet to match the efforts or garner the impact of twentieth-century Black nationalists, particularly those at their apex prior to $1975 .^{2}$

Unquestionably, twentieth-century Black nationalists articulated valuable ideas, and organized programs based on a foundation that recognized the importance of Black humanity, self-determination, self-defense, and intra-racial solidarity. Diverse in their approaches, focus and application in terms of belief systems, institutions, cultural expression, psychological reclamation, social programs, economic reform, and even curricular development, all Black nationalists to some degree remained committed to the liberation of Black people. ${ }^{3}$

While Black nationalist efforts have historically remained mostly positive, responses to this mode of Black self-determination from the U.S. media, government, law enforcement, Black accommodationists, and the wider public, then and now, have generally stayed negative. Media outlets and other institutions have labeled those associated with Black nationalism as domestic terrorists and hate mongers. Even with their diversity in terms of goals and strategies, those connected with Black nationalist thought or views continued to be seen uniformly as irrational radical extremists and temporary irritants who refuse to bend to existing mechanisms of white social control and Black accommodationism. ${ }^{4}$

Since at least 1917, this country has witnessed the rise and fall of twentieth-century Black nationalist leaders, programs, organizations, institutions, and movements. Still, one of the most consistent and strident voices of twentieth-century Black nationalism persist today, the Black Muslims in the Nation of Islam and their leader Minister Louis Farrakhan. This essay argues that Farrakhan and the reconstituted Nation of Islam or NOI has not only stayed on message by continuing to prioritize Black self-determination but they have also attempted to simultaneously provide the most important dimensions of Black nationalism since the late 1970s. Consequently, the NOI, particularly Farrakhan, stands as the last influential voice of twentieth-century Black nationalism. Farrakhan's eventual departure, and the subsequent decline of the NOI, will likely leave a substantial vacuum in the Black nationalist tradition for the first time in over one hundred years. ${ }^{5}$

(Sullivan 2016; Johnson 2017, Issue 163, pp. 44-47; Van Deburg 1997, p. 1).

(Trodd 2015, p. 34; Van Deburg 1997, p. 5).

See Southern Poverty Law Center Hate Group Listings, Marshall Project “Black Identity Extremists," and a number of articles and social media sites that call Black Lives Matter advocates terrorists (Beydoun and Hansford 2017; Deese 2020).

5 See (Glaude 2002; Joseph 2006; Levy 1998; Moses 1996; Ogbar 2004; Robinson 2001; Taylor 2011; Van Deburg 1997). I use reconstituted to differentiate between the NOI from 1930 to 1975 and then 1979 to present for historical clarity when necessary. 
Twentieth-century Black nationalism can be traced back to Marcus Garvey's Universal Negro Improvement Association (UNIA). Garvey, and his wives Amy Ashwood, and later Amy Jacques, were responsible for the second wave or renaissance of Black nationalism in the United States in the early 1900s. Garvey took the lead to remove the manacles of racial oppression by prioritizing economic and social Black self-determination. The Universal Negro Improvement Association's leadership worked hard to create institutions that sought to raise the consciousness and socioeconomic station of Black people. Garvey also aspired to break the physical (through emigration) and psychological (miseducation) ties that bonded African peoples to their former slave masters and colonizers. Though the movement was thwart with problems, Garvey and his UNIA followers had a great deal of success. With powerful rhetoric and strategies to acquire economic independence such as the establishment of the Black Star Line, the Negro World newspaper, and other Black business ventures, Garvey raised the hopes and aspirations of working-class Black people. Within just ten years after coming to the United States, Garvey found himself under government surveillance, the target of the Black elite, surveilled, arrested, then imprisoned, and eventually deported. As a result, the Garvey movement in the U.S. became irreparably fractured. Moreover, on account of saboteurs within his organization, and his poor management skills, and status as a so-called outsider, the Garvey movement in the United States was short lived, leaving very little behind outside of a few followers, and his philosophy and lessons written and later published by his wife Amy Jacques Garvey. Consequently, Garvey's exile, in addition to other challenges mentioned, resulted in the deterioration of UNIA businesses, and the like; and, a movement that was once popular, strong and vibrant, became nearly extinct in the United States. Despite these failures, Garvey laid an important foundation on which to build subsequent movements.

According to William L. Van Deburg, James L. Taylor, Peniel Joseph, Jeffrey Ogbar, Eddie Glaude, and other scholars, several individuals and groups revived the philosophy and aspirations of Black nationalism after the decline of the Garvey movement in the United States. For example, the African Blood Brotherhood (ABB) recaptured the attention of those with Black nationalist leanings. Cyril Briggs, founder and leader of the group, established what Van Deburg called a "secret order" in 1919 "which possessed both fraternal and paramilitary characteristics." Comparable to other Black nationalist organizations, the ABB attempted to address some of the wider Black community's most pressing issues, as they saw it, including colorism, economic dependency and instability, Black self-esteem, and the need for religious and historical reclamation. The ABB eventually became absorbed by the Communist Party of the United States of America (CPUSA); and Briggs became its national secretary. By the late 1920s, the ABB had waned, and no institution remnants of the organization remained that would continue their specific Black nationalist goals and mission. ${ }^{6}$

Like the Garvey movement and ABB, most of the twentieth-century campaigns and organizations that appeared between the 1920s and 1960s had at least three components-economic, cultural, and educational uplift. In terms of economic development, a few emphasized self-help initiatives such as Black entrepreneurship such as opening up restaurants, department stores, newspapers, bakeries, and other businesses. Other proponents centered their efforts on Black consumerism. For example, the Buy Black Campaigns encouraged Black consumers to purchase products that would help advance Black commerce and build wealth within the community. These tactics were two pronged, in that they not only sought to increase support for Black businesses but to also undo the psychological effects of white hegemony that led some Black people to believe that anything sold or created by Black people was inherently inferior. Moreover, this strategy intended to undercut European American businesses in Black neighborhoods that mistreated, cheated and took advantage of Black consumers. In 1941, "Carlos Cooks organized the African Nationalist Pioneer Movement." Cooks economic scheme focused on the Buy Black Campaign, which he argued would place Black people in a position to "control the businesses in Black neighborhoods" and ensure financial survival through "economic cooperation."

6 (Van Deburg 1997, pp. 34-35). 
Cooks advice to buy Black for the most part fell on deaf ears and the movement for stable, lucrative, and permanent Black businesses in Black communities ultimately failed, particularly outside of the South. Yet, calls to build and support businesses by and for people of African descent remained a central facet of Black nationalism throughout the twentieth century. ${ }^{7}$

From the 1930s to the late 1960s, other groups that focused on efforts by and for Black people were mostly local. However, much larger groups with more national appeal included the original Nation of Islam, the US Organization, and the Black Panther Party for Self Defense, as the more popular. The US Organization, founded by Maulana Karenga in 1965, possessed some Black nationalist aspects but prioritized cultural reclamation. Karenga's group centered African culture and prescribed cultural unity as a strategy to combat white supremacy. In October 1966, Huey P. Newton and Bobby Seal founded the Black Panther Party (BPP). While Seal was named Chairman, Newton became the Minister of Defense. Their decision to form the BPP not only came out of their respect for the conscious-raising work of Malcolm X, and by extension the Nation of Islam, but also the desire to bring an end to the oppression of Black people in general and the public execution of Black men in particular at the hands of police. The Black Panther Party, though not Black nationalist per se, pulled from Black nationalist rhetoric, and promoted nationalist programs and ideas. For instance, their desire for community policing to end police brutality against oppressed peoples helped align them with many Black nationalist viewpoints. In addition, their call for political activism and education that centered on the Black experience, breakfast programs, health clinics, the Black Panther newspaper, and calls for self-defense exemplified some of the most important qualities of twentieth-century Black nationalism. Moreover, while they did not support racial separation, they did encourage certain aspects of it such as Black people controlling their own schools and communities, such as the BPP Oakland community school established in $1973 .^{8}$

Twentieth-century advocates of Black nationalism, even if they only embraced certain aspects, helped to frame, legitimize and advance a new Black identity that was self-determining, community centered, and strongly situated in Black consciousness. Black men, particularly those associated with the BPP, such as Stokley Carmichael, Rap Brown, and Huey P. Newton, became some of the most important Black nationalist icons of the twentieth century. While socioeconomic class was central to the BPP's mission and understanding of the racial problem in America, and culture was central to the US Organization, both realized the importance of racial solidarity, identity, and unity among Black people. Akin to so many Black nationalist campaigns and organizations, the Black Panther Party was momentary because of internal strife; government infiltration; the assassination, exile and incarceration of leaders; and complex gender politics. Like the Garvey movement, the BPP found itself in sharp decline and nearly eradicated within ten years after its founding. ${ }^{9}$

The organizations briefly outlined here, from the UNIA to the BPP, projected some of the most important twentieth-century Black nationalist ambitions. Other groups, mostly small, or former advocates of integration, such as the Student Non-violent Coordinating Committee (SNCC), and Congress of Racial Equality (CORE), moved toward a Black nationalist platform by the end of the 1960 s to some extent in practice but mostly in terms of rhetoric. Groups that embraced some aspect of Black nationalism were relatively small, irrelevant, disbanded, or ineffectual by the late 1970s. The only groups to broaden its appeal and continue well into the late twentieth and twenty-first centuries were the programs and ideas of the original Nation of Islam, although not without significant change.

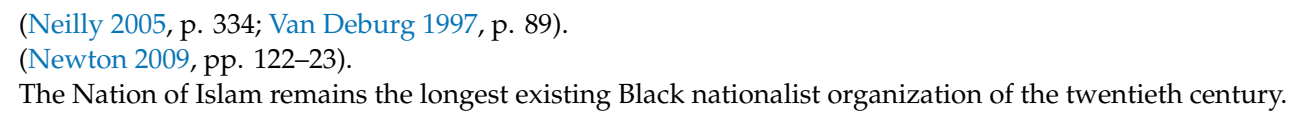




\section{The Last Voice of Twentieth-Century Black Nationalism}

4 July 2020 marked the 90th anniversary of the Nation of Islam. The original Nation of Islam, under the leadership of Clara and Elijah Muhammad, represented one of few Black nationalist groups that established a national and later international enterprise, such as their private schools, H\&G Whiting imports, and Muhammad Speaks newspaper. Established in 1930 in Detroit, MI, the NOI operated department stores, clothing factories, a printing press, restaurants, bakeries, a bank, grocery stores, farms and other endeavors, similar to the Garvey movement but more robust. Elijah Muhammad's program, philosophy, and leadership, though often overlooked by scholars for his tremendous contributions, were some of the most important and successful articulations of twentieth-century Black nationalism. Muhammad's strategy of racial upliftment helped turn former convicts, drug users, and Black people who lacked meaningful purpose into upstanding members of Black communities and the wider society. For the first time, those cast aside as unimportant, unintelligent and criminal became morally upright, family-centered homeowners, and entrepreneurs. Men and women associated with the Nation of Islam attempted to implement the most potent elements of Black nationalism-economic advancement, re-education, conscious raising and spiritual recovery. Lastly, the Nation of Islam produced some of the most powerful leaders and spokesmen for Black self-determination in the twentieth century, one of whom was Minister Louis Farrakhan.

Louis Farrakhan joined the Nation of Islam in 1955. By 1960, Farrakhan became the lead minister of Boston Temple No. 11; and, by 1967, Elijah Muhammad appointed Farrakhan to Malcolm X's previous position, national spokesperson for the NOI. From 1967 to 1975, Farrakhan held both the role of national spokesperson and the minister of New York Temple No. 7. Farrakhan oversaw the rebuilding of Mosque No. 7 after the 1965 bombing, which was said to be in retaliation for the assassination of Malcolm X in February 1965. Although he had a difficult time winning over what some have referred to as Malcolm's Harlem, Farrakhan eventually succeeded in building a strong base. Under his leadership, the New York NOI no longer rented the restored Temple but owned the building. The new structure housed a school, restaurant, bookstore, health food store, and bakery in addition to the Temple. As Minister and spokesperson for the NOI, Farrakhan's popularity and power expanded in the late 1960s and early 1970s, represented by his appearance on shows such as Soul! Television on WNET in New York, and the success of the annual Black family celebration. Because of his oratory skills, and ability to rebuild the reputation of the Harlem temple, other Black leaders, organizations, and students from all over the country invited him to speak at various venues. For instance, "Farrakhan often spoke on the same platform with other notable Black leaders ... including being one of the first speakers who addressed the first National Black Political Convention, held in Gary Indiana ... [in 1972]." By 1974, Farrakhan easily attracted large audiences with "more than 70,000 [attending] his Black family Memorial Day lecture in New York."10

Though things seemed to be going well for Farrakhan in his capacity as NOI national spokesman and Minister of the New York temple, in 1975, after the death of Elijah Muhammad, W.D. Mohammed, as the new leader of the Nation of Islam, made significant changes to the organizational structure including moving Farrakhan from New York to Chicago, and eliminating his post as national spokesperson. A few years later, Farrakhan split with the original NOI, renamed the World Community of Islam (WCOI) and later American Muslim Mission (AMM), to "lift the name, defend the honor, spread the message, and rebuild the work of the Honorable Elijah Muhammad." With the departure of Farrakhan, the original NOI now split into two major groups, the WCOI/AMM, and the reconstituted Nation of Islam (RNOI), both of which rightly claim the historical legacy of the original Nation of Islam. Although there were a few other offshoots, none flourished compared to Farrakhan's group. Though the WCOI/AMM and the RNOI share an important past, they pursued different aims from 1978 onward. Under the leadership of W.D. Mohammed, the WCOI/AMM struggled to juggle warring ideologies—the desire to

10 (Marshall 1996, p. 84; Walker 2005, p. 485). 
be more aligned with traditional Islam, the need to embrace American patriotism and, to a certain degree, to remain allied with the Black struggle for freedom, justice and equality. By the late 1980s, the WCOI/AMM's historic legacy and commitment to Black nationalism, as well as weighing in on American racial politics, mostly faded, and conventional Islamic and American cultural acceptance and assimilation became prioritized. ${ }^{11}$

Farrakhan, among one of the first to see and contest the move toward a divestment in an unapologetic agenda for Black self-determination, left the group with the desire to reclaim the legitimate spirit of the Nation of Islam, i.e., reestablishing the community as a self-determining, authentic, economic, unified, and informed voice for Black people in the late 1970s. Like W.D. Mohammed, Farrakhan also sought to do a balancing act. He too would seek to align the RNOI with so-called orthodox Islam, to a degree; but unlike the WCOI/AMM, his group would prioritize the Black struggle for freedom, justice and equality over adherence to a more conventional Islam, and reject the movement toward uncritical American patriotism and assimilation, similar to Elijah Muhammad. With his previous experience as Minister, and National Spokesman for the Nation, Farrakhan successfully raised additional money and "reestablished the NOI, expanded his following, reinstituted the annual Saviour's Day celebration, rebuilt the international empire, and [quickly resumed his position] as one of the most powerful and popular black leaders in the U.S. and abroad, particularly among young Black people." 12

From the 1980s to late 1990s, Farrakhan worked hard to restore the presence of the NOI in nearly every city in the U.S., and outside the country including Bermuda, where the original NOI had existed, and as a result, his popularity soared both nationally and internationally, especially after the 1995 Million Man March. However, in a post-civil rights-Black power landscape, Farrakhan faced a great deal of criticism, media misinformation, and controversy. Still, he accomplished tremendous feats as the leader of the reconstituted NOI by forging partnerships with other Black organizations, such as forward-thinking Black church leaders like Jeremiah Wright and spreading the NOI message of racial uplift. Wherever he went, Farrakhan packed "every auditorium he visited with people across the wide socioeconomic and religious spectrum of the Black community." According to Marshall, more than "5000 people, representing different organizations from various cities and states" attended Farrakhan's first NOI Saviour's day held in February 1981, and in August, 1983 as an invited speaker, Farrakhan addressed the significant gathering for the twentieth anniversary of the March on Washington. In December of 1983, he traveled with Jesse Jackson to Syria, and he helped secure "the release of Navy Pilot Lt. Robert O. Goodman Jr." As an example of Black solidarity, Farrakhan registered to vote for the first time in order to back Jesse Jackson's run for the U.S. presidency in 1984 and encouraged his followers to do the same. Marshall argues that because of Farrakhan's political gesture, one hundred and sixty-seven Muslims registered that day. Farrakhan's willingness to openly support Jackson inspired other Muslims and "a large sector of the militant black nationalist movement which had previously opposed electoral participation" to get involved. ${ }^{13}$

Many detractors and critics of Black nationalists, Farrakhan, and by extension the Nation of Islam, align their programs and philosophy with Black supremacy or Black capitalism. Some find their goals unattainable and outdated, while others accuse Black nationalists such as Farrakhan of anti-Semitism, toxic masculinity, racial bigotry and homophobia. But, despite these beliefs and accusations, Farrakhan, like Malcolm X, and Muhammad Ali before him, became a sought-after voice at universities and colleges across the country in the 1980s and 1990s. Though some attempted to undercut his freedom of speech, challenged students' rights to invite him to campuses, and whites and their Black allies attempted to discredit Farrakhan and his Nation of Islam, his following and support grew stronger.

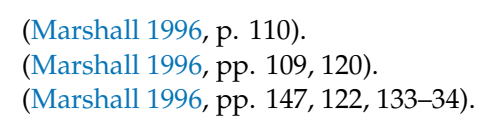


Given the tremendous controversy, student demonstrations, and efforts to intimidate Black student organizations such as the Black Student Union, who invited him, Farrakhan's visits to campuses such as Michigan State and Northern Illinois University in the 1990s resulted in a ban for nearly a decade from many colleges and universities across the country. Amid this backlash against Black nationalist aspirations and voices, particularly at colleges and universities, Farrakhan continued to work on reestablishing Clara and Elijah Muhammad's efforts, and to propagate their Islamic ideologies grounded in Black nationalism.

The spiritual component of his NOI programs, though at times steeped a bit in aspects of old-world superstitions, helped reposition Islam as a healthy, pro-Black, and life-changing alternative for Black people. The educational component, also revitalized, promoted self-education, self-help, and a positive Black identity from childhood to adulthood, all of which Farrakhan saw, like his predecessors, as integral to the survival and advancement of Black people. More specifically, Farrakhan reinitiated other original NOI programs that sought to undo and eventually eradicate the damaging legacy of white supremacy including severe Black unemployment, substance abuse, destruction and separation of the Black family, and community violence (securing the internal safety of the Black community). As such, the reconstituted Nation of Islam continued work in the area of drug use recovery by instituting a drug program that successfully helped reduce drug use among Black people. They also maintained their community protection efforts. In attempts to quell Black animosity and violence in areas such as Chicago, New York and Washington DC, the Nation of Islam dispatched security details made up of the Fruit of Islam (FOI), the paramilitary arm of the group, which several politicians and leaders acknowledged. In 1988, "D.C. Council member, H.R. Crawford ... supported the Muslims," and as recent as 2012, "Mayor Emanuel of Chicago enthusiastically welcomed the NOI, even while under attack from those of the Jewish community" who saw Farrakhan as anti-Semitic. Former Mayor Daley of Chicago also embraced the work of the reconstituted NOI in Chicago as he had done with the original NOI in the 1960s, as they helped to bring peace between rival gangs, implemented a clinic for drug abuse, and developed an adopt-a-prisoner program to help decrease recidivism. ${ }^{14}$

The Nation of Islam attempted to create alliances between African Americans, Native Americans, and Latino and Chicano Americans to work toward reducing drug addiction and crime and improve the conditions of socioeconomic suffering in those communities. Community control of Black spaces, and building alliances with other oppressed groups, helped to bolster the NOI's platform and popularity. For example, in 2006, Farrakhan met with Navajo leaders such as President Joe Shirley in an effort to improve relations between Black and Indigenous peoples. He also tried and succeeded in increasing the NOI's Latino membership, particularly in the LA area. ${ }^{15}$

\section{Economic Articulations of Self-Determination}

Farrakhan and the Nation of Islam continued commitment to twentieth-century Black nationalist ideas, actions, philosophies and perspectives is most evident in their economic goals, conscious-raising efforts and critique of European-American imperialism and white supremacy.

Though most of the NOI's attempts to restore Muhammad's economic programs met with failure, Farrakhan believed that the unique economic problems of Black people remained critical and required several approaches to succeed. First, he insisted Black people must address "their own unemployment concerns." Next, there was a need to revitalize efforts that focused on Black Business by reinitiating a Buy Black Campaign, similar to the earlier Black nationalist initiatives. Additionally, the need for Black manufacturing required some attention. In 1991, Farrakhan revived Elijah Muhammad's three-year economic savings program. This community savings program sought to combat persistent poverty in the Black community. He later collaborated with Al Wellington, founder of the Wellington Group, to

14 (Marshall 1996, p. 189; Walker 2005, pp. 517-18).
15 (Newsmakers 2006, p. 35). 
implement "People Organized and Working for Economic Rebirth" or P.O.W.E.R. as a way to help build economic independence for Black people. As a means to elicit unity, foster community allegiance, and establish an economic base, Farrakhan suggested to "secure yourself and your family by establishing a business providing a service or product that fulfills a community need." He went on, "If you can provide food, clothing and/or shelter-if you can enhance the mind and spirit you are well on your way to making a measurable contribution toward the independence of your community." With forces meant to disrupt Black communities such as gentrification, urban renewal, massive displacement of entire areas, and environmental factors such as contaminated water, the stability and socioeconomic advancement of Black communities stand as important staples of any Black nationalist agenda. Farrakhan argues, "living in close proximity to each other increases political and economic power as well as the quality of life." The P.O.W.E.R. program encouraged Black people to manufacture basic daily items "like soap, deodorant, toothpaste, lotion ... as well as other household items." At the core of these efforts remain initiatives by and for the advancement of Black people. ${ }^{16}$

Before widespread popularity of the farm-to-table movement, Farrakhan worked to revive the original Nation's farming system in order to produce "foods that [were] uninfected with pesticides and other chemicals that facilitate poor health" and to make them widely available in Black communities. By 1995, Farrakhan purchased Elijah Muhammad's former home for $\$ 500,000$, and again successfully operated several "security firms that ... won government contracts to patrol crime-ridden black neighborhoods." The NOI also purchased some land in the Midwest and opened Salaam Restaurant \& Bakery in Chicago. In 2015, the Nation held an agriculture seminar at Muhammad's farm in Buffalo, Michigan, saying "Farming is the Engine of our National Life." Nation One Communications, "a long-distance service and telecommunications company", was also founded by the NOI. In the Los Angeles area, the Muslims established a food co-op to develop a "partnership with black farmers throughout California to produce crops for the cooperative." Few of these ventures were stable, widely supported, or long term, although some remain in operation. ${ }^{17}$

The Final Call newspaper represents one of the few economic ventures that the reconstituted NOI pursued that appears to be the most successful. Although it is uncertain just how profitable the paper has been, it is disseminated in every major city in the United States, online, and worldwide. The Final Call picked up where Muhammad Speaks, the original NOI mouthpiece by and for Black people, left off. It remains one of the few international, independent, outspoken, and unbought Black nationalist newspapers founded in the twentieth century. The paper covers issues sometimes ignored by the mainstream media, and even some Black media outlets, and helps to highlight not only the problems that plague Black people but also other racially marginalized groups, their contributions, and accomplishments. It is a paper that includes the experiences and challenges of all people who remain racially ostracized. The Final Call unapologetically covers the abuse of power by the U.S. government and military on less powerful countries such as Iraq, Iran, Afghanistan, Libya, and Syria. The NOI has been particularly critical of the illegal and savage murders of Iraq and Libya leaders, which left these countries severely unstable. Lastly, the Final Call maintains a close eye on American dealings with Iran and provides a needed account of Israel and its dealing with Palestinians. The newspaper continues to shine a light on the duplicitous nature of American foreign affairs in Latin America, and has maintained an important record of domestic hate crimes, "police terrorism," and other domestic terror attacks against people of African descent not only in the U.S. but also throughout the world since the 1980s. The NOI paper chronicles the Black and Brown struggle and the fight against injustices generally overlooked by other media outlets such as the 2007 ICE round up of undocumented workers, civil suit against Denny's in East St. Louis in which a Black family won $\$ 60,000$ for racial discrimination; a Black mother's fight (Felicia Wilson) to see justice against a now closed Bowling Brook Preparatory

16 (Marshall 1996, pp. 167-69, 173; Van Deburg 1997, p. 322).

17 (Marshall 1996, pp. 169, 173; Muhammad 2015; Walker 2005, p. 521). 
School responsible for the death of Felicia Wilson's son; and, Fair Housing violations in places such as Milwaukee, WI. ${ }^{18}$

Farrakhan, and the Nation of Islam, have stayed committed to their economic blueprint for self-determination, a core component of twentieth-century Black nationalism, through their newspaper, farms, restaurants, schools, and other business ventures.

Although the economic platform remains significant, the NOI continues to recognize the need to eradicate Black self-hate as well. Nearly all groups-the Universal Negro Improvement Association, the African Blood Brotherhood, the African Nationalist Pioneer Movement, the Black Panther Party, the US Organization, the Shrine of the Black Madonna, the original Nation of Islam, and other groups-tried to address Black internalized hatred, even if marginally. Generally, three major approaches to the issue of self-hate persisted in the twentieth century-building brick and mortar institutions to help shift the tide of educational indoctrination and miseducation; the outright challenge to white supremacists' normative ideas of beauty and intelligence in writings, speeches, music, and art; and redefining Black religiosity and the conceptions of G-d. All of these methods proved essential to helping to upend internalized racism and allowed Black people to see themselves through a new and more positive perspective.

\section{Educational Articulations of Self-Determination}

The schooling of Black children is central to cultural awareness and upliftment. Black nationalists recognized the tremendous need for both schools and educational programs by and for people of African descent to undo the psychological damage of historical white supremacy. Black Muslims addressed this concern by removing their children from public schools. When Nation members decided to educate Black children in the 1930s, their makeshift schools eventually became the first K-12 private Muslim school system in the United States. The Black Panther members founded weekend schools. Their education program intended to challenge the misrepresentation and miseducation found in traditional public schools. The BPP schools also helped to raise the political consciousness of young Black people. The US Organization sought to re-educate through cultural initiatives such as the implementation of Kwanzaa, a cultural holiday and other programs. Other groups also offered some kind of educational initiative, with Saturday and after school programs becoming the most popular. A few independent Black schools were also founded such as Lotus Academy in Philadelphia, PA, Nation House Watoto Shule in Washington, DC, and Omowale Ujamaa School in Pasadena, CA. Recently, though not independent several charter schools have also attempted to do some of this work, although with great limitations. These liberation schools educated Black children about their history, self-defense, and the evils of capitalism and white supremacy. The original Nation of Islam created a

18 (Baylor 2010, p. 33; Damu 2007, p. 16). I reviewed the Final Call paper since 2007. The Black Muslim paper covers a broad range of topics domestically and internationally. For instance, domestic issues include racial injustice and terrorism, housing foreclosures in black communities, housing and employment discrimination, unemployment, police brutality, health disparities, government corruption, and international issues such as the Iraq war and issues in Africa, Latin America and Caribbean. Sample articles include "12 December Movement leads 'a day of outrage' against NYPD terrorism," 2 October 2007, p. 7; “U.S. tries to blunt Cuba, Venezuelan health initiatives in Latin America," 2 October 2007, p. 9; “The war economy and the costs of war, part II," 2 October 2007; "A message of atonement comes to the incarcerated," 28 October 2008, p. 5; "Millions Unemployed: What does major rise in joblessness mean for Black America's future?" 4 November 2008, p. 3; "Police Brutality on the upswing, advocates warn," 4 November 2008, p. 2; "Cigarette Smoking and Lung Cancer: A Deadly Mix, Especially for Black Males", 16 November 2008, p. 29; “Corruption: The American Way of Life," 23 December 2008, p. 3; "Mass Murder in Gaza Strip: Israeli attacks on Palestinians condemned worldwide, but U.S. stands with aggressor nation", 13 January 2009, p. 3; "The exploitation of Africa's land and people", 17 February 2009, p. 9; "Stringent anti-immigration law has activist wondering: How Far Will It Go?" 18 May 2010, p. 3; “Katrina: Five Years of Pain," 7 September 2010; "Muslims Establish Organic Farm in Georgia," 25 October 2011, p. 6; "Killing Gadhafi," 1 November 2011; "Who Defines Black Women?" 10 January 2012, p. 3; "Taking Away Your Rights: National Defense Authorization Act lays foundation for targeting political dissenters, activism," 17 January 2012, p. 3; “Carving Out A United Caribbean," 17 April 2012 ; “Investing in Black America's Future," 29 October 2013; "Farrakhan, Iran \& Election 2016," 8 March 2016; "Black Mother Fights for Justice," "Another Denny's Pays the Price," "Fair Housing Council wins' discrimination case," Final Call, 2 October 2007, p. 10. 
K-12 national and later international independent school system. As of 2019, many of those schools, many in operation for more than fifty years, have closed. ${ }^{19}$

Louis Farrakhan's Nation of Islam was never able to reach the success of the original NOI in terms of educational institutions. Although there are some NOI (reconstituted) schools, few have achieved the reputation of the former Muhammad Universities, renamed the Sister Clara Muhammad Schools in the late 1970s. The NOI's Chicago school is likely the most successful. It stands next to the NOI headquarters, mosque Maryam. The Muhammad school, like earlier Islamic universities, offers not only typical subjects such as math, reading and science but also Arabic, Islamic Studies and Physical Training (self-defense). Farrakhan sees the inability to maintain these kinds of autonomous Black institutions, as well as a failure to support Black schools in general, as the miscarriage of the Black elite who he argues dismiss Black nationalist efforts and self-determination, and do not see the benefits of this particular aspect of Black nationalism. In July 2010, Farrakhan penned a letter to Black leaders. In the letter, he highlighted the inability of the Black elite to effect positive change amid the masses of Black people. He said "No matter how rich and powerful some of us have become we have never been shown how to network with the wealthy and the learned of our people, pooling our resources, that we may produce for our people that which would grow us from a begging position as little children to become masters of our own destiny." Essentially, given the conditions of public schools and the overall miseducation of Black youth, Farrakhan envisions that wealthy African Americans are positioned to do more in terms of establishing their own schools in the United States, and at minimum in the communities from which they came to assist in the intellectual upliftment of Black people. ${ }^{20}$

Historically, the Nation of Islam underscored the unfortunate realities faced by Black children in American schools; the RNOI continues to do so today. Most majority-Black schools still lack appropriate resources, Black teachers, and Black history. Instead, what young people see and learn in most schools continues to undermine self-determination and promote the belief of white superiority and Black inferiority.

Just a little more than sixty years ago, the Brown v. Board decision gave hope to some Black people who believed that the Supreme Court's ruling would lead to better conditions and outcomes for Black children. Yet, more than sixty-five years later, Black students continue to endure inequities in their schooling. According to the Urban Leagues' 2014 report on the State of Black America, "White students are three times more likely than Black students to be at or above proficient in Reading and 3.4 times more likely to be at or above proficient in math." Moreover, "while the high school graduation rate for Americans is improving the achievement gap between racial groups persist. Black students have the lowest rate of high school graduation among all racial groups." The report states that students unable to secure "a high school diploma ... will have fewer opportunities, much lower wages," and likely experience higher incidence of health problems. Consequently, quality education by and for Black youth remains fundamental to any Black nationalist agenda and remains especially encouraged by the NOI. In a 1996 interview with Professor Henry Louis Gates, Farrakhan said "I think the worst enemy of this country and all the countries of this earth is neither white nor Black nor Jew nor gentile but ignorance. The hallmark of a true democracy is the enlightenment of the people. In addition, where ignorance prevails democracy cannot be. We have to [seriously] look at the purposeful destruction of the American educational system." Some people, who bend toward Black nationalist ideas, have attempted to address the persistence of educational inequality by establishing charter schools; but, these efforts lack the real autonomy and self-determination indicative of twentieth-century Black nationalist initiatives. ${ }^{21}$

19 "Black Mother Fights for Justice," p. 10; Dr. Maulana Karenga was not a Black nationalist and therefore is not suggested as one of the last voices of twentieth-century Black Nationalism. He is included given the period and his important contributions during the period as it concerns aspects of Black Nationalism but more specifically cultural nationalism.

20 (Farrakhan 2010).

21 (State of Black America 2014, p. 104; Farrakhan and Gates 1996). 
Farrakhan and the reconstituted Nation of Islam's message of education is not solely for those in the K-12 system. His Nation of Islam is a staunch supporter of Historically Black Colleges and Universities (HBCUs) and views the education of young Black people in those institutions closely linked to the economic success, survival, advancement, and self-sufficiency of the wider Black community. In 2012, there was renewed interests in the NOI's message. That year, Louis Farrakhan received a number of invitations to visit HBCUs by various student groups. The popularity and number of requests turned this into Farrakhan's Black College tour. Like his early university tours in the 1970s, 1980s and 1990s, Farrakhan's visits were not without significant controversy. In typical fashion, white detractors of Farrakhan tried to put considerable pressure on the administrators and students at various universities to prevent his trip though to no avail. Advocates of freedom of speech do not extend such courtesies to groups that relay a challenge to the rhetoric of the status quo and white supremacy.

In April of 2012, Farrakhan visited with students at Alabama A\&M University, Tennessee State University, Lemoyne Owens College and the University of Arkansas at Pine Bluff. In March 2013, Farrakhan traveled to Tuskegee University. In November 2014, Morgan State University Student Government Association invited Louis Farrakhan as their keynote speaker for the 2nd Annual Black United Summit International. While there, Farrakhan spoke about the importance of HBCUs and the need to support them not only materially but also by encouraging more Black students to opt for enrollment at HBCUs in place of predominantly white institutions. He argued that the move toward dismantling HBCUs was a direct assault and halt to the fight for Black liberation, and he highlighted the fact that some of the Black communities best and most vibrant leadership in the 1960s came from the ranks of HBCUs. He went on to say that everything must be done to maintain these institutions. Farrakhan urged students to major in disciplines that would not simply equip them to get a job but to create jobs. In this area, Farrakhan, like his original NOI predecessors, encouraged Black students to seek degrees important to nation building such as agriculture, mathematics, medicine, engineering and the like. He said, "you have new buildings (at the university) but you're not producing new minds. You're not being taught the disciplines that will make you a nation builder, you're being taught that which will cause you to come out of here looking for a job-and the jobs don't exist anymore." He goes on, "get a degree in something that will allow you to build a future for yourself and your people." His most recurring message was economic and educational development, the very tenets of twentieth-century Black nationalism. ${ }^{22}$

Like the original NOI, Farrakhan continues to carry the banner of racial uplift and community responsibility, and encourages Black college students, and soon to be graduates, to invest in institutions that will help them to be productive citizens for their family, community, society, and the world. Farrakhan's other college visits included the March 2012 U.C. Berkley's Afrikan Black Coalition conference which brought together student from all over California, and more recently Winston Salem University in May 2016 among others. It is clear that like other twentieth-century Black nationalists, Farrakhan continues to capture the attention and respect of Black people as evident in his college invitations to Morgan State University, Tuskegee, Prairie View, and other colleges and universities across the country between 2012 and 2016 .

\section{One Nation: International Dimensions of Black Self Determination}

"Just four months after the Million Man March in October 1995, Farrakhan took his message abroad in his World Friendship Tour. Visiting '23 nations in 35 days'." Farrakhan visited places such as Sudan, Libya, Nigeria, and Iraq. As a result of his growing international status, and association with so-called enemies of the U.S., Farrakhan was accused by U.S. State officials as "cavorting with terrorists". While some denounced his travels abroad especially to places considered adversaries to American democracy, others celebrated his message of Black (and to a lesser degree Muslim) unity

22 (Farrakhan 2012, 2014). 
and atonement. In a November, 2012 article in the New Amsterdam newspaper, during his Caribbean tour from Jamaica to Cuba, Farrakhan remarked about the need for a Caribbean coalition, similar to past calls for a United Africa. During his 1996 visit to Libya, the late Muammar Qaddafi "pledged $\$ 1$ billion to Louis Farrakhan to help uplift the Black race in America." Lastly, Farrakhan collaborated with national and international leaders to create an international economic fund, though unsuccessful. When Qaddafi visited the U.S. in 2009, Farrakhan and the Nation of Islam, a long time and strong supporter of the then Libyan ruler, said of Qaddafi that "he was on the frontline of many [Black] liberation struggles including ones focused on freeing Mandela, the anti-Apartheid movement in South Africa, and the continued Palestinian struggle."23

Twentieth-century Black nationalists, such as Farrakhan and the Nation of Islam, have always had a complex but important relationship with not only other colonized and oppressed peoples throughout the world but also those who oppose Western Judeo-Christian imperialism. Black self-determination remains an important foundation to build Black [and Muslim] diaspora support. Since at least the mid-1990s, Louis Farrakhan has enjoyed global celebrity. Like his predecessor, Elijah Muhammad, Farrakhan's message possesses international allure and application not only in its unique brand of Islamic religiosity but also in its ability to remain anchored in the most important aspects of Black self-determination, Black unity, Black spirituality, self-help, educational uplift, and economic development.

Like some earlier twentieth-century Black nationalists, such as Garvey, the Nation of Islam continues to call for an African diaspora coalition. The NOI is the last strident voice against American imperialism and global white supremacy. In June 2011, Farrakhan criticized President Barak Obama for his "decision to commit U.S. military forces to strategic airstrikes in Libya." In the Final Call, Farrakhan provided a compelling critique of the American government in terms of their complacency regarding domestic terrorism as it concerns Black people within U.S. borders, and their violence and duplicity against the international community, particularly Muslims. In a 2007 speech, titled "Under One God," Farrakhan said regarding the Bush administration, "they got us in a war that destroyed the economy. All of them are liars. All of them are murderers." While so-called Black leaders in general, and Black people in particular, stay silent on the issues related to an ethnocentric American foreign policy, Farrakhan and the NOI attempt to keep the masses of Black people informed, and provide an alternative lens and critical analysis of the American government's international dealings. ${ }^{24}$

In terms of the Israeli and Palestinian conflict, the NOI also remains very outspoken, drawing parallels between the illegal war in Iraq, the war on Palestinians and Islam, and the one being waged against African Americans in the United States. Farrakhan described rockets launched by Israel's against Palestinians as "a continuation of the history and bloody policy of the Zionist state and its unapologetic effort to virtually exterminate civilians and wipe Palestine off the map." He has often spoke of 9/11 as a justification to invade Iraq, and to later assassinate Saddam Hussein. Moreover, according to Farrakhan, the U.S. did not go into Libya to help the people but to strengthen the opposition against Muammar Qaddafi and hopes of removing him from power and installing someone more friendly to U.S. capitalists' interests. He said, "Listen to the hypocrisy [of the] American people ... is it that American government is so concerned over the blood that is being shed in Libya, but you looked the other way when the Israeli Defense Force was bombing the innocent people of Gaza, unnamed men, women and children? Where were you in Rwanda? Where are you in the Congo?" The NOI remains critical of the growing anti-Muslim rhetoric of U.S. government officials since $9 / 11$. Farrakhan claims that African Americans must remain vigilant concerning Western imperialism and should place so-called terrorism in a historical context. He averred, "Terrorism is a response to oppression. We should be asking ourselves what have Europeans and Americans done to drive people to such great

23 (Marshall 1996, pp. 24, 240, 241; Jones 1996; Arinde 2009, p. 32).

24 Ebony, June 2011, p. 22. Ebony.com; (Farrakhan 2007). 
lengths?" He goes on "We must recognize the common issues we face as non-White people of the world and turn to each other and repair our relationships." Historically, one of the Nation's and other Black nationalists' most important and most celebrated characteristics was their ability to shine a light on racially and economically motivated offenses by Western powers who continue to criminalize and terrorize non-white peoples with impunity through military action and economic sanctions. Farrakhan and the Nation of Islam's continued significance, prioritization of Black self-determination, and by extension the importance of twentieth-century Black nationalist sentiments lie in the ability to disrupt mainstream narratives of misinformation, and the powerful and persistent messages of Western white supremacy. ${ }^{25}$

\section{The Black Nationalist Tradition}

The Nation of Islam prioritizes Black self-determination. The Do for Self, Love Thyself, and Know Thyself principles of the group remain a central theme of their rhetoric and their works. The NOI reestablished educational institutions and businesses in the U.S. and abroad, particularly in Bermuda and London, though not to the degree of the original Nation. They continue to link the twenty-first-century Black American struggle for human rights with the broader Muslim struggles of Palestinians, Syrians, Afghans, Iraqis, and the like, fighting against Western Judeo-Christian imperialism, and European-American capitalist interests. American Black nationalism, particularly the NOI agenda, continues to be linked to the African diaspora struggle against colonial white supremacists' socioeconomic control and encroachment.

Louis Farrakhan successfully attracted Nation of Islam supporters all over the world in Europe, Africa and the Caribbean. He met with various heads of state from Africa and the Middle East including Robert G. Mugabe, Saddam Hussein, and Muammar Qaddafi. He effectively secured monetary support from Libya in order to help build up his enterprise in the 1990s. Farrakhan has been only one of a few nationally and internationally recognized Black leaders to call for the U.S. government to either "try or release" the Guantanamo Bay detainees. In 2005, he also called for "a multi-faith [and race] delegation of Americans to go to Guantanamo" to investigate the reports of abuse and the "desecrations of the Qur'an at Guantanamo Bay". ${ }^{26}$

The NOI newspaper has continued to cover the Iraq and Afghanistan conflicts, and critique the United States for what they see as "its real" intentions of capitalistic imperialism, and war crimes that continue unabated. ${ }^{27}$

For more than sixty years, Farrakhan has provided an important voice and assessment of the persistent and purposeful socioeconomic poverty and racial violence directed toward Black people. The NOI remains one of the most consistent and important organizations that came out of the twentieth-century spirit of Black nationalism. Though the NOI's major focus continues to be on unemployment, education, global affairs, and health-related issues, it also continues to address Black love and family. In the case of the Black family, the NOI remains a strong advocate of marriage and monogamy. Future scholars may want to examine the marriage and divorce rates of this community compared to other groups given the attention, encouragement, and support provided to build and maintain healthy Black families. The Nation of Islam continues to encourage Black solidarity, institution building, self-pride, and economic self-sufficiency. Even in the twenty-first century, the NOI believes that these tenants are essential to increasing the life chances and opportunities for people of African descent.

In 2020, Black people continue to deal with many of the same obstacles and limitations to their psychological and socioeconomic well-being that the Nation seeks to address-a bankrupt

\footnotetext{
"Obama, Farrakhan, and the Muslim Dilemma," Ebony Magazine, 2011, p. 22. Ebony.com.

(Walker 2005, pp. 46, 546).

(Walker 2005, pp. 542-44).
} 
educational system; family disruptions and separations; toxic, dilapidated and unstable housing; high unemployment; self-hate; and health disparities that continue to expand, particularly with the onslaught of COVID-19 deaths and Black infant mortality. As such, I think the spirit and philosophy of twentieth-century Black nationalist remains necessary.

There is no other formal articulation or platform of twentieth-century Black nationalism today, outside of the NOI. Louis Farrakhan and the NOI continue to lay bare long-held notions that maintain and advance the narrative of white superiority and Black inferiority most evident in the American media and educational institutions. Accordingly, Farrakhan and the NOI are the last strident voice of twentieth-century Black nationalism. Although the number of members in the Nation of Islam are unknown, his following and supporters clearly go beyond formal membership given the millions who show up to his annual events and other affairs. Farrakhan is one of very few who can convene Black leaders from across the spectrum, from Congressman Danny K. Davis, Dr. Cornell West, Father Michael Pfleger of Saint Sabina Church in Chicago, IL Russell Simmons, Reverends Al Sharpton and Jeremiah Wright, to the late Dorothy Height, and others as he did with the 2005 Millions More Movement in Washington D.C.

When the last voice of twentieth-century Black nationalism is silenced, what national and international voices will continue to articulate the possibilities for the masses of Black people to re-inspire, restore, and renew Black communities? What twentieth-century Black nationalist tools may still be useful for a new generation of Black activists? Or, does Black nationalism no longer hold importance for the liberation of Black people? How will twenty-first-century Black nationalist proponents address the persistent issues of racial strife and inequality; and what new paths may they forge in the protracted struggle for human rights? Finally, what might be learned from the Nation of Islam and Farrakhan's leadership, both successes and challenges, that may pave new ways and envision new strategies in the battle for Black self-determination and liberation ${ }^{28}$

Funding: This research received no external funding.

Conflicts of Interest: The author declares no conflict of interest.

\section{References}

Arinde, Nayaba. 2009. Libya's Qadhafi and Farrakhan in NYC Next Week. The New Amsterdam News, September 17-23.

Baylor, Leroy. 2010. Farrakhan uses Saviour's Day to address the believers and has a message for President Obama. The New York Amsterdam News, March 4-10.

Beydoun, Khaled, and Justin Hansford. 2017. The FBI's Dangerous Crackdown on 'Black Identity Extremists.'. New York Times Online. November 15. Available online: https://www.nytimes.com/2017/11/15/opinion/blackidentity-extremism-fbi-trump.html (accessed on 16 November 2020).

Damu, Jean. 2007. Rounding up undocumented workers: Reflection on the ICE Raids. Final Call, October 2.

Deese, Kaelan. 2020. Giuliani says Black Lives Matter is a 'domestic terrorist' group. The Hill. August 6. Available online: https://thehill.com/homenews/media/510953-giuliani-says-black-lives-matter-is-domestic-terroristgroup (accessed on 16 November 2020).

Farrakhan, Louis. 2007. Minister Louis Farrakhan Calls for Unity during 'One Nation under God' Speech on Saviour's Day. Ebony Magazine, March 12.

Farrakhan, Louis, and Henry Louis Gates Jr. 1996. Farrakhan Speaks. Transition 70: 140-67. [CrossRef]

Farrakhan, Louis. 2010. Open Letter to Black Leadership. Final Call, July 20.

Farrakhan, Louis. 2012. Farrakhan Speaks at TSU Event. November 1. Available online: http://www.fox19.com/ story/19981158/louis-farrakhan-to-speak-at-tsu-event-friday (accessed on 5 August 2017).

28 Perhaps a new and formal Black ideology and agenda may emerge after Farrakhan and his Nation of Islam but it will not be the black nationalism of the twentieth century, even if we see remnants as we are seeing now in the various calls and initiatives under the umbrella of Black Lives Matter. 
Farrakhan, Louis. 2014. The 2nd Annual B.U.S.I. Conference: 'Re-Claim, Re-Pair, Re-Form, Re-Produce-REPARATIONS Now!'. Final Call. December 2. Available online: http://www.finalcall. com/artman/publish/minister_louis_farrakhan_9/article_101968.shtml (accessed on 5 August 2017).

Glaude, Eddie S. 2002. Is It Nation Time?: Contemporary Essays on Black Power and Black Nationalism. Chicago: University of Chicago Press.

Johnson, Daryl. 2017. Return of the Violent Black Nationalist: Ambush Cop Killings among Other Murders Motivated by Hate. Intelligence Report. Montgomery: Southern Poverty Law Center.

Jones, Charisse. 1996. Farrakhan Defends His World Tour before a Receptive Crowd in Brooklyn. New York Times. May 14. Available online: http://www.nytimes.com/1996/05/14/nyregion/farrakhan-defends-his-world-tourbefore-a-receptive-crowd-in-brooklyn.html (accessed on 17 August 2017).

Joseph, Peniel. 2006. The Black Power Movement: Rethinking the Civil Rights-Black Power Era. New York: Routledge.

Levy, Peter B. 1998. The Civil Rights Movement in America: From Black Nationalism to the Women's Political Council. Westport: Greenwood.

Malcolm, X. 1964. The Ballot or the Bullet. In Civil Rights Since 1787: A Reader on the Black Struggle. Edited by Jonathan Birnbaum and Clarence Taylor. New York: New York University Press.

Marshall, A. 1996. Louis Farrakhan: Made in America. Johnsonville: BSB Publishing.

Moses, William Jeremiah, ed. 1996. Classical Black Nationalism: From the American Revolution to Marcus Garvey. New York: New York University Press.

Muhammad, Starla. 2015. Nation of Islam Michigan Farm host agriculture seminar. Final Call, July 31.

Neilly, Herbert L. 2005. Black Pride: The Philosophy and Opinions of Black Nationalism. Indiana: Authorhouse.

Newsmakers. 2006. Farrakhan Visits Navajo Nation. Jet Magazine, July 20.

Newton, Huey P. 2009. Revolutionary Suicide. New York: Penguin Books.

Ogbar, Jeffrey O. 2004. Black Power, Radical Politics and African American Identity. Baltimore: The Johns Hopkins University Press.

Robinson, Dean E. 2001. Black Nationalism in American Politics and Thought. New York: Cambridge University Press.

State of Black America. 2014. Urban League Report. Available online: http://soba.iamempowered.com/soba-boo (accessed on 5 August 2017).

Sullivan, Kevin. 2016. The Rise of Black Nationalist Groups that Captivated Killers in Dallas, Baton Rouge. Washington Post. July 23. Available online: https://www.washingtonpost.com/national/inside-the-blacknationalist-groups-that-captivated-killers-in-dallas-baton-rouge/2016/07/23/e53aef66-4f89-11e6-a42283ab49ed5e6a_story.html?utm_term=.59e5badfe249 (accessed on 5 August 2017).

Taylor, James L. 2011. Black Nationalism in the United States: From Malcolm X to Barack Obama. Boulder: Lynne Rienner Publishers.

Trodd, Zoe. 2015. Black Nationalism. In The Civil Rights Movement in America: From Black Nationalism to the Women's Political Council. Edited by Peter B. Levy. Santa Barbara: Greenwood Press.

Modern Black Nationalism: From Marcus Garvey to Louis Farrakhan. 1997. Van Deburg, William L., ed. New York: New York University Press, pp. 3-4.

Walker, Dennis. 2005. Islam and the Search for African American Nationhood: Elijah Muhammad, Louis Farrakhan and the Nation of Islam. Georgia: Clarity Press.

Publisher's Note: MDPI stays neutral with regard to jurisdictional claims in published maps and institutional affiliations.

(C) 2020 by the author. Licensee MDPI, Basel, Switzerland. This article is an open access article distributed under the terms and conditions of the Creative Commons Attribution (CC BY) license (http://creativecommons.org/licenses/by/4.0/). 